\title{
Review on Recent Aspects of Biochemical, Cellular, Physiological Markers and Environmental Factors Associated with Acute Lung Inflammation \& Injury (ALI)
}

\author{
Venkanna Bhanothu ${ }^{1}{ }^{\text {** }}$, Jane Theophilus ${ }^{1}$, Roya Rozati ${ }^{2}$, Prabhakar Badhini ${ }^{3}$, Boda Vijayalaxmi ${ }^{1}$, \\ Kalyan Reddy $\mathbf{P}^{3}$ \\ ${ }^{1}$ Dept. of Zoology, UCS, OU, Hyderabad. India \\ ${ }^{2}$ MHRT Hospital and Research Centre, Road No\# 3, Banjara Hills, Hyderabad, India \\ ${ }^{3}$ Dept of Anthropology, School of Social Sciences, University of Hyderabad, Hyderabad, India
}

\begin{abstract}
Acute Lung Inflammation \& Injury (ALI) is a patho-physiological response to interaction of various factors at biomolecular and cellular level and the physiological condition leading to enhancement of the same in contamined environmental conditions. This review aims to discuss the current status of research done in the area of ALI and unique in that it projects a combination of new simulations, experiments and schemes which were not proposed earlier in targeting the ALI at many areas. Utilization of biomarkers in medicine enhances the capacity to detect and support diagnosis of disease for early prediction and for planning therapeutic alternatives. Novel investigation and innovative understanding at molecular level revealed an abundance of exciting arena of new biomarkers which suggests their use for clinical observations. For the last four decades, the search has continued for useful diagnostic and prognostic biomarkers that can enable and guide critical care physicians to precisely distinguish ALI/ARDS from other disorders and to portend disease progression. Quite a few new molecules as biological markers in acute lung inflammation and injury have had clinical applications. The scope of this exhaustive review is to summarize the current status of some biochemical, cellular, physiological markers and role of environmental factors in acute lung inflammation and injury.
\end{abstract}

Keywords Acute Lung Inflammation, Injury (ALI), Acute Respiratory Distress Syndrome (ARDS), Biomarkers

\section{Introduction}

With improved understanding of patho-physiology of disease, many biomarkers have been assessed for diagnostic or prognostic capability. The identification of such a biomarker would enable improved clinical decision-making, therapy management, social support and better utilization of healthcare resources. The use of markers in medicine lies in their ability to detect disease and support diagnostic and therapeutic decisions. New research and novel understanding of the molecular basis of the disease reveals an abundance of exciting new markers which present a promising hope for use in the everyday clinical practice.

The initial evaluation of biomarker concerns its level of expression in patients with the disease and in normal individuals in order to define sensitivity and specificity. The sensitivity of a test is defined as the proportion of patients with disease having a positive test whereas the specificity is

* Corresponding author:

venkanna_82@yahoo.co.uk (Venkanna Bhanothu)

Published online at http://journal.sapub.org/ajb

Copyright (C) 2012 Scientific \& Academic Publishing. All Rights Reserved the proportion of patients without the disease who have a negative or normal test. In 2001, the NIH adopted a definition for a biomarker as "an indicator of normal biologic processes, pathogenic processes, or pharmacologic response $\mathrm{s}$ to a therapeutic intervention." A biomarker that indicates pathogenic processes and is involved in molecular pathways will guide researchers in further understanding intricate disease mechanisms, so that novel therapeutic interventions may be developed[1]. The validation of biomarkers, for use in clinical trials and ultimately in practice, has become a central tenet of translational biomedical research[2]. Measurements of biomarkers in both the airspaces and plasma early in the course of acute lung injury have provided new insights into the mechanisms of lung injury. Therefore, the following few parameters are looked for screening of serum level of an ideal marker[3]:

1) Pathological increase in the presence of the disease (high sensitivity),

2) Normal in the absence of the disease (high specificity),

3) Risk or prognosis

4) Varied interpretations of clinical evaluation

5) Feasibility of measurement of illness

6) Anticipation of the clinical changes like relapse 
7) Disease burden and level

8) Accuracy and consistency (as determined by the low coefficient of variation),

9) Trouble-free, simple timely and cheap determination.

Rationally, a useful biomarker might conceivably predict either responsiveness (i.e. the inflammatory component) or the risk of progression of disease. Another key benefit a biomarker might provide is more accurate prognostic information from change in that biomarker, especially if the information can be obtained rapidly. If current non-invasive and semi invasive tools predict outcome very accurately, a biomarker will add extra information of value. Therefore, it simply needs to provide more accurate information about progressiveness than current modalities, not independent information. Regarding serial monitoring, whether or not a biomarker is highly reproducible is less crucial than clear quantification of the reproducibility, in order to distinguish between true change and measurement "noise". A marker might be poorly reproducible and yet highly accurate when it does clearly change. Moreover, there is confusion between diagnostic and prognostic requirements. A diagnostic marker needs to be sensitive and specific. However, a prognostic biomarker could, in principle, be normal when disease is present but stable. Alternatively, based on the conception that the best diagnosis is prognosis, the most useful diagnostic marker will be the one that separates patients against the disease-specific outcomes[4]. The interplay between sensitivity, specificity and the nature of the disease under prediction assigns suitable cut-off points. A number of novel blood biomarkers of lung disease including cytokines, enzymes, adhesion molecules, collagen relevant products and products of type II epithelial cells, have been studied for their clinical applicability. In addition, biologic markers of cell-specific injury, acute inflammation, and altered coagulation correlate with mortality from acute lung injury in several single centered studies as well as in multi-centered clinical trials. Acute lung injury instigates a myriad of cellular and molecular cascades that result in circulating inflammatory and pro-thrombotic mediators; pathophysiolo gic disturbances that may be important determinants of mortality. The clinical need for a biomarker in acute lung inflammatory disease regarding the presence or absence of the disease, the histospecific diagnosis and the prediction of responsiveness has probably little value. An indicator of poor prognosis that may encourage referral to a specialist center would need to be available within hours, whereas a marker of ventilator-associated lung injury (VALI) that was being used to fine-tune ventilator settings would have to be "turned around" within minutes. No biomarkers that are currently available have penetrated routine clinical practice with the possible exception of the use of procalcitonin (PCT) to diagnose sepsis in critically ill patients and to guide their antibiotic therapy[5]. Unfortunately, this search has been hindered by the inherent heterogeneity of the disease along with the consistent lack of correlation between biochemical markers, pathophysiologic variables and clinical outcomes. Procalcitonin levels correlated with severe sepsis and bacteraemia[6], but did not consistently differentiate survivors from non-survivors, in finale the biomarker showed good specificity but low sensitivity[7]. The current definition of ALI/ARDS is such that biomarkers of the established syndrome are largely redundant. Most studies have attempted to correlate selected biomarkers with disease severity or death, which is potentially useful both clinically to help target resources and more expensive or invasive management strategies, and in helping to power research studies using mortality as the primary outcome. Biomarkers potentially combined with physiological and genomic data should be used to identify patient groups for research studies and individuals who are most likely to gain from targeted therapies. There are two separate therapeutic goals in ALI: a) a short term response as judged by improvements in pulmonary function test (PFT) and regression of imaging abnormalities as judged mainly by high resolution computed tomography (HRCT); and b) slowing or prevention of refuse. On the other hand, clinical necessity becomes invaluable regarding the baseline prediction of rate of progression and the early prediction of progression based on serial change with treatment. This will allow anti-inflammatory or other treatments to be evaluated or eventually modified before they have failed. Inflammation is central to virtually all lung injury syndromes in the newborn and adult. The acute lung injury and its more severe counterpart acute respiratory distress syndrome (ARDS) are defined by radiographic and physiological changes that characterize patients with acute lung failure. Animal models of acute lung injury /inflammation are important tools for studying mechanisms relevant to the acute respiratory distress syndrome (ARDS) in humans. Many methods, in a variety of different animal species, can generate ALI, each with its own set of advantages and limitations[8].

\subsection{Prevalence of Acute Lung Inflammation}

Despite advancement in understanding the pathophysiolo -gy of ARDS and improved life support of patients with this form of acute respiratory failure, mortality of 50 to 90 percent remains common in published reports. A common and highly morbid inflammatory syndrome, is characterized by increased pulmonary endothelial and epithelial permeabi -lity leading to alveolar flooding and a mortality $>35 \%[9]$. Recent studies have estimated the incidence of these conditions to be between 15 and 34 cases per 100,000 inhabitants per year showing an overall mortality rate of $30-40 \%[10]$. It produces nearly 200,000 hospitalizations and 16, 000 deaths in the United States each year[9]. Epidem iologically, direct ALI accounts for $57 \%$ of all cases and is caused mainly by pneumonia, aspiration, and lung trauma. Indirect ALI accounts for the residual 43\% with non pulmonary sepsis being the most frequent underlying disease. Bhadade et al reported, the etiology of ALI/ARDS is mainly tropical infectious diseases, i.e. malaria $(27.6 \%)$, leptospirosis $(20.7 \%)$, malaria with dengue $(5.2 \%)$, and undiagnosed fever (27.6\%), while pneumonia (13.8\%), urinary tract infections (3.4\%) and pancreatitis $(1.7 \%)$ 
contributing to the remaining[11]. Bajpai and Bichile noticed $22 \%$ mortality due to malaria, $22 \%$ due to leptospirosis, and $54 \%$ due to undiagnosed fevers[12]. A significant proportion of these patients had ARDS (28.2\% clinically and $48.6 \%$ post autopsy). Avanti Vigga and Mantri in 2003 found that the primary pulmonary infection has been associated with ARDS in $25 \%$ of patients and sepsis was a significant risk factor[13]. Despite recent advances in mechanical ventilatio $\mathrm{n}$ and numerous clinical trials of novel pharmacological agents, understanding of pathophysiology of the disease; the mortality of ARDS remains very high ranging from $40 \%$ to $60 \%$. ALI/ARDS results from direct (e.g. pneumonia, aspiration of gastric contents, pulmonary contusion, etc.) and indirect causes (e.g. sepsis, trauma, fractures, pancreatitis, burns, etc.). Recognition that the disease represents an uncontrolled inflammation of the lung has led to some important developments for treatment but even today mortality hovers around 60 percent for those people in whom the disease was identified early enough to initiate treatment.

\subsection{Definition of Acute Lung Inflammation}

Inflammation is a characteristic of lung diseases; asthma, chronic obstructive pulmonary disease, and cystic fibrosis are chronic inflammatory lung diseases each characterized by the involvement of specific molecular mediators and cellular components of inflammation[14]. In addition, contaminant molecules that foster inflammation have been shown to exacerbate the development and severity of lung diseases. Acute inflammation of the lung is a poorly recognized human disease that develops in surprising and unexpected ways. Pattern of widespread lung inflammation is also called Acute Lung Injury (ALI) and increased pulmonary vascular permeability depicted by pulmonary edema and hypoxia. It is a syndrome of rapid-onset bilateral pulmonary infiltrates of non cardiac origin, characterized by alveolar capillary injury, inflammation with neutrophil accumulation with hemorrhage, and release of proinflamma -tory cytokines which often results from severe pulmonary infection or trauma and can progress to acute respiratory distress syndrome (ARDS), which is characterized by profound inflammation and tissue injury[15]. It is a life-threatening disorder produced by diverse stimuli (pneumonia, sepsis, trauma, gastric acid aspiration) with unacceptable morbidity and mortality is characterized by complex spatially-defined multicellular activation and inflammatory cell influx.

\subsection{History of Acute Lung Inflammation}

Precedent to the development and widespread use of positive-pressure ventilators, acute lung injury and ARDS, often termed double pneumonia, were nearly universally fatal forms of respiratory failure. However, Ashbaugh and colleagues in 1967 described the clinical entity that they called "acute respiratory distress in adults," positive-pressure mechanical ventilation was an important component of the care of patients with acute respiratory failure, and it was clear that this therapy was vital to the survival of patients with ARDS[16]. A wide variety of animal models have been developed to explore both the pulmonary and non-pulmonar y sequelae of acute lung injury. Common to a majority of these models has been the description of a diffuse inflammatory reaction in the lung's microvasculature. The recognition that neutrophils, macrophages, and other components of the inflammatory cascade participate in the progression of ALI has resulted in the use of anti-inflammat ory agents as pharmacologic probes to further define the pathophysiology of this syndrome. It was recognized in the mid-1980s that ARDS resulted in a significant reduction in the amount of normally aerated lung tissue. The "baby lung" that is typical of ARDS patients were markedly over distended by high tidal volumes[17]. Regardless of the wide variety of insults that cause or contribute to the development of ALI, the response of the lung is largely stereotypic. A combination of tissue injury and inflammation affecting the gas exchange surface of the lung, the alveolar capillary membrane, causes high permeability pulmonary edema. The presence of a protein-rich inflammatory exudate in the airspace impairs surfactant function. Loss of pulmonary capillary surface area associated with localized lung destruc -tion and occlusion of the vascular bed by intravascular thrombosis, increases the anatomical dead space, itself associated with a poor outcome. The consecutive three-phase pathological model of ALI (exudative, proliferative and fibrotic) is a gross over-simplification. Fibrosis is evident histologically as early as a week after the onset of the disorder and procollagen III peptide, a precursor of collagen synthesis, is elevated in the broncho-alveolar lavage (BAL) fluid of ARDS patients at the time of tracheal intubation. Several pro-inflammatory mediators are also pro-fibrotic, distinct patterns of gene expression are associated with acute inflammation and fibrosis in the injured lung, suggesting that fibrosis is not simply an inevitable consequence of unresolv -ed inflammation. Indeed, current thinking emphasizes the primary role of disordered epithelial repair, which may be contributed to by repeated or persistent injury and inflamma tion, in driving a pathological fibrotic response[18].

\subsection{Types of Acute Lung Inflammation}

Pleurisy cases are either classified as being "wet" or "dry". The wet kind of lung inflammation is more common and refers to the accumulation of fluid within the spaces of the lining of the lungs. This excess fluid may arise from many different causes like virus, parasites, or bacteria, starts the immune response which then leads to inflammation, that causes blood and lymph fluid to accumulate which makes breathing very difficult. Pain occurs with pleural effusion since the fluid which causes the lung inflammation forces the membrane surfaces apart. Therefore, "wet" pleurisy causes even more complications as it places more pressure on the lungs. This may lead to respiratory distress and one's lung may even collapse. Dry pleurisy is lung inflammation without the build-up of fluid. This can make the two layers of 
the pleura rub together and cause pain. The pleura are composed of two layers. It is made up of an inner layer that surrounds the lungs and the outer layer which lines the chest cavity. These pleural membranes are quite thin and are very close together. A fluid coating sits in the narrow space between the two layers. The pleura consist of two layers: one that covers the lung and the other that covers the inner wall of a person's chest. These two layers stay lubricated by the pleural fluid. Pleurisy is often associated with pleural effusion. This is when extra fluid accumulates in the space that separates the two layers of pleura.

\subsection{Pathophysiology and Risk factors of Acute Lung Inflammation}

The core pathology is disruption of the capillary -endothelial interface: this actually refers to two separate barriers - the endothelium and the basement membrane of the alveolus. In the acute phase of ALI, there is increased permeability of this barrier, and protein rich fluid leaks out of the capillaries. There are two types of alveolar epithelial cells - Type 1 pneumocytes represent $90 \%$ of the cell surface area, and are easily damaged. Type 2 pneumocytes are more resistant to damage, which is important as these cells produce surfactant, transport ions and proliferate and differentiate into Type 1 cells. The damage to the endothelium and the alveolar epithelium results in the creation of an open interface between the lung and the blood, facilitating the spread of micro-organisms from the lung systemically, stoking up a systemic inflammatory response. Moreover, the injury to epithelial cells handicaps the lung's ability to pump fluid out of airspaces. Fluid filled airspaces, loss of surfactant, microvascular thrombosis and disorganiz ed repair (which leads to fibrosis) reduces resting lung volumes (decreased compliance), increasing ventilation-per fusion mismatch, right to left shunt and the work of breathing. In addition, lymphatic drainage of lung units appears to be curtailed - stunned by the acute injury: this contributes to the build up of extravascular fluid. Prolonged inflammation and destruction of pneumocytes leads to fibroblastic proliferation, hyaline membrane formation and lung fibrosis. This fibrosing alveolitis may become apparent as early as five days after the initial injury. Subsequent recovery may be characterized by reduced physiologic reserve, and increased susceptibility to further lung injuries. Extensive microvascular thrombosis may lead to pulmonary hypertension, myocardial dysfunction and systemic hypotension. Loss of pulmonary capillary surface area associated with localized lung destruction and occlusion of the vascular bed by intravascular thrombosis, increases the anatomical dead space, itself associated with a poor outcome, giving rise to carbon dioxide retention. Host factors, both inherited[19] and acquired, influence individual susceptibility. Precipitating causes or risk factors, which often "hunt in packs", either affects the lung directly (pneumonia, aspiration of stomach contents and thoracic trauma) or because ALI indirectly through a systemic inflammatory response syndrome (SIRS) related with multiple organ dysfunction, exemplified by brutal sepsis and transfusion related ALI[20]. The options for alveolar failure are either alveolar replacement, via some form of extracorporeal gas exchange device, or a strategy for maximising endogenous alveolar function. Acute lung inflammation is secondary to sepsis, trauma, drug overdose, primary cause remains unknown.

Table 1. Characteristics of human lung injury

\begin{tabular}{|c|c|}
\hline Clinical features & Acute onset \\
\hline Physiological changes & Diffuse bilateral alveolar injury \\
\hline & Acute exudative phase \\
\hline & Repair with fibrosis \\
\hline & V/Q abnormalities \\
\hline & Severe hypoxemia \\
\hline Biological changes & Decreased compliance \\
\hline & Impaired alveolar fluid clearance \\
\hline & Increased endothelial and epithelial permeability \\
\hline & Increase in cytokine concentrations in the lungs \\
\hline Pathological changes & Protease activation \\
\hline & Coagulation abnormalities \\
\hline & Injury of the alveolar epithelium with denudation of the basement \\
& membrane \\
\hline & \\
\hline &
\end{tabular}


The following symptoms can occur: stabbing pain in one's chest that is aggravated by breathing, tenderness in the chest area, cough, and one may also experience shortness of breath. There can be many causes of pleurisy or lung inflammation, these include the following: infections, collagen vascular diseases of which rheumatoid arthritis and lupus are two examples, cancers which may include metastatic lung cancer or even breast cancer, tumours that are found in the pleura, heart failure, lung embolism which is when a blood clot is found in a vessel that goes to the lungs. Pleurisy is an inflammation of the lining of the lungs that occurs with pain. This happens when an infection or a damaging agent irritates the lung lining or the pleura. As a result, one experiences sharp chest pains as the main symptom. Characterized by excessive alveolar distension which causes the tight junction of the alveolar wall to rupture and caused when the lungs are directly damaged by over ventilating given in (Table 1).

\subsection{Diagnosis of Acute Lung Inflammation}

Sampling the epithelial lining fluid by bronchoalveolar lavage (BAL) represents the common means of studying the proteins secreted by the lung epithelium and investigating their alterations in lung disorders. Since years scientists led by pioneering studies that showed the presence of these proteins in the bloodstream as well, even though in small amounts, demonstrated using enzyme-linked -immunosorbe -nt assays (ELISA) significant variations of these proteins' levels in the serum of patients with different acute inflammatory diseases. The latter suggests that their assay might represent a novel approach in the assessment of lung diseases with still elusive pathogenesis, prognosis, diagnosis and therapeutic interventions. Because these proteins are mainly, if not exclusively secreted within the respiratory tract, their occurrence in the vascular compartment can be explained by several hypothetical mechanisms including leakage from the lung into the bloodstream, resulting from the increased permeability of lung vessels, the destruction of the barrier between alveolar epithelium and endothelium caused by injury to the basement membrane. Increased production by the alveolar type II cells coupled with an increase in total type II cells per lung due to diffuse hyperplasia and diminished clearance rates from the circulation. The early serial measurement of this biomarker may lead to an early detection of relapse and thereby allow anti-inflammatory and other treatments to be evaluated or eventually modified before they have failed. The latter components can potentially compile a clinician's "wish list". On the basis of this conception, an important number of serum markers either lung-specific proteins and cancer -associated antigens or cytokines and other serological parameters probing different aspects of the immunopathoge -nesis of acute lung inflammatory disease has been delineated. Initial reports of these markers shed further light into the pathophysiology of acute lung inflammatory disease[21] improved diagnostic and prognostic capabilities [22] and ultimately, led to a better patient care. Although the applications of these markers in the clinical setting created major expectations, however the feeling of excitement comes in contrast with important deficiencies exhibited by the new methodologies including non-standardization techniques, lack of knowledge of reproducibility and link to disease behaviour. Moreover, most of the studies enrolled a limited number of patients, insufficient to extract any meaningful or statistically significant outcome.

\section{Objectives}

Very little is known about the biomarkers associated with acute lung inflammation and injury. Confusion prevails about association of several factors in the pathogenesis of ALI. The role of specific biomarker is doubtful in early detection of the disease because all these factors are compulsorily involved in the cascades of reactions. These reactions are interlinked and it is very difficult to establish specific biomarker for the diagnosis of disease. Keeping these in mind we have proposed to summarize the current status of biochemical, cellular, physiological markers and role of environmental factors associated with acute lung inflammation and injury, this gives scope to suggest the possible bimolecules as biomarkers in detecting the acute lung inflammation without any uncertainty.

Table 2. Literature search results

\begin{tabular}{|c|c|c|c|c|}
\hline Terms used in search engine & $\begin{array}{c}\text { Google search } \\
\text { engine citation } \\
\text { results }\end{array}$ & $\begin{array}{c}\text { PubMed-NCBI } \\
\text { search engine } \\
\text { Articles }\end{array}$ & $\begin{array}{c}\text { PubMed } \\
\text { Central }\end{array}$ & $\begin{array}{c}\text { NCBI Online } \\
\text { Books }\end{array}$ \\
\hline $\begin{array}{c}\text { Review on Recent Aspects of Biochemical, Cellular, } \\
\text { Physiological markers and Environmental factors Associated } \\
\text { with Acute Lung Inflammation \& Injury (ALI) }\end{array}$ & 35,900 & 39 & nil & nil \\
\hline $\begin{array}{c}\text { Recent Aspects of Biochemical, Cellular, Physiological markers } \\
\text { and Environmental factors Associated with Acute Lung } \\
\text { Inflammation \& Injury (ALI) }\end{array}$ & 43,100 & 44 & nil \\
\hline $\begin{array}{c}\text { Biochemical markers Associated with Acute Lung Inflammation } \\
\text { Cellular markers Associated with Acute Lung Inflammation }\end{array}$ & 326,000 & 432 & 510 & nil \\
\hline $\begin{array}{c}\text { Physiological markers Associated with Acute Lung } \\
\text { Inflammation }\end{array}$ & $1,090,000$ & 132 & 1066 & 3 \\
\hline $\begin{array}{c}\text { Environmental factors Associated with Acute Lung } \\
\text { Inflammation \& Injury (ALI) }\end{array}$ & 104,000 & 136 & 464 & 3 \\
\hline Acute Lung Inflammation & $3,420,000$ & 22455 & 5960 & 201 \\
\hline Acute Lung Injury & $2,000,000$ & 12459 & 4687 & 40 \\
\hline
\end{tabular}




\section{Methods}

This is an informative review study suggested by group of scientific community of Osmania University (OU), Hyderabad, Andhra Pradesh, India with a view to give clear characteristics developments in this area. Literature reviews was carried out in Computer Centre at CFRD collaborator research centre $\mathrm{OU}$ which is connected by high speed internet facilities, and have permission to open all international and national journals, e-journals and books. Several internet associated search engines including Pubmed-NCBI, Google and other source like libraries were used for collecting the data. Articles have been retrieved from search engine by using specific term such as "acute lung inflammation", "acute lung injury", "biochemical marker associated with acute lung inflammation", "cellular marker associated with acute lung inflammation", "physiological marker associated with acute lung inflammation and injury" and "environmental factors associated with acute lung inflammation \& injury (ALI)". Retrieved research articles, review articles, chapters from books, conference proceedings, seminar presentations and abstracts were systematically studied. The related information from these articles were snowballed, corrected and presented without any difficulty in a systematic way. Enormous information got out of search has been selectively collected and rest of the unwanted was excluded.

\section{Results}

Using Google search engine (https://www.google.co.in/\# $\mathrm{hl}=$ en\&output $=$ search\&sclient) about 35900 citations were noted on use of the title "Review on Recent Aspects of Biochemical, Cellular, Physiological markers and Environmental factors Associated with Acute Lung Inflammation \& Injury (ALI)". Using PubMed-NCBI search engine (http://www.ncbi.nlm.nih.gov/pubmed) about 39 articles were identified; out these 12 are related to the topic of investigation. Details of search engine results have been given in table 2. Search results indicates that the very little information about 'Recent Aspects of Biochemical, Cellular, Physiological markers and Environmental factors Associated with Acute Lung Inflammation \& Injury (ALI)" have been documented though unrelated information can also be seen during the search, which has not been taken in to consideration. Presently, there is need to provide quality review articles to boost up the ideas among the scientific communities. This review article attempted to summarize the current status of biomarkers associated to acute lung inflammation.

\section{Discussion}

The mechanisms linking a distant focus of infection to remote lung inflammation remain elusive. The commonly held view is that bacterial toxins released into the circulation activate interconnected inflammatory cascades in the lung, leading to diffuse alveolar damage. Specific inflammatory mediatory molecules and issues have been summarised in table 3[23-47]. Rojas and co-workers reported that intraperitoneal Etx administered to $\mathrm{C} 57 \mathrm{~B} 1 / 6$ mice caused increased expression of various inflammatory mediators, increased lung water, and increased neutrophil accumulation in lung tissue[48]. Bacterial-lipopolysacchari-de (LPS), a component of the outer cell wall of gram-negative bacteria, has been so far held responsible for triggering this chain of events. Whether additional bacterial toxins play a role in the development of acute pulmonary inflammation during gram-negative sepsis remains an unresolved issue. In animals, a marked increase in SP-D in BALF has been reported following lung inflammation induced by silica, LPS, and Pneumocystis carinii infection. Mast cells can function as effector and immunoregulatory cells in IgE-associated allergic disorders, as well as in certain innate and adaptive immune responses. Mast cells are involved in the development of various $\mathrm{T}$ cell-associated immune responses in mice, neutrophil-associated lung inflammation in ovalbumin (OVA)-challenged, OVA-specific T cell receptor transgenic mice[49]. Tremblay et al observed that high tidal volume ventilation in rats resulted in increased levels of inflammatory mediators (i.e., tumour necrosis factor- $\alpha$, interleukin IL-6, and IL-10) in BAL fluid[50], and von Bethmann et al confirmed that increased levels of tumour necrosis factor- $\alpha$ and IL- 6 are released into the circulation from lungs ventilated with high tidal volumes[51]. Large multicenter trials have reported elevated levels of mediators, like soluble tumour necrosis factor-alpha receptors (sTNFR) 1 and 2, soluble intercellular adhesion molecule-1[52] and interleukin (IL)-6 were associated with adverse outcomes in patients with ALI. VALI plays a major part in the pathogenesis of ALI and, as a result, many large studies have been performed examining the effects of ventilator strategies, a lot has been learned about the responses of popular biomarkers in patients undergoing protective and standard ventilation[53]. Hence, circulating mediators ofinflammati-on (sTNFR), IL-6, -8 and -10 , indicators of epithelial cell injury (soluble advanced glycation end-product receptors (sRAGE)[54] and surfactant protein-D[55] and components of the coagulation system (protein-C and plasminogen activator inhibitor-1[56] have all been promoted as biomarkers of VALI. It has been observed a significant increase in lung inflammation after six cycles of Social disruption stress. Greater numbers of neutrophils and monocytes were present in the lungs after Social disruption and a greater percentage of neutrophils were in an activated state compared to those in control lungs. The increase in inflammatory cells was not a result of increased vasculature permeability but likely a result of increased levels of the chemokines KC, MIP2 and MCP-1, as well as increased expression of adhesions molecules P-selectin, E-selectin, and ICAM-1 within the lungs. Recent data demonstrate the priming effects of Social disruption on the lung microenvironment and emphasize the need to 
further investigate the role of psychosocial stress in other diseases that are characterized by lung inflammation. Such research could lead to a greater understanding of the development of pulmonary disease and new therapeutic approaches that reinstate appropriate glucocorticoid regulation ofinflammat-ion in underlying disease states or immune challenges. It would be surprising if there was not considerable overlap between markers of VALI, tissue injury, inflammation and a poor prognosis. In further, these biomarkers inevitably lack specificity for individual processes or outcomes. Moreover, these mediators have multiple effects, have no specificity to the lung and there is no convincing evidence that manipulating the inflammatory response benefits patients with ALI.

Table 3. List of reported biomarkers along with partial description[23-47]

\begin{tabular}{|c|c|c|c|}
\hline Factors & Description & Limitations & References \\
\hline $\begin{array}{c}\text { Cytokines and } \\
\text { Chemokines and other } \\
\text { Inflammatory } \\
\text { mediators: } \\
\text { IL-1 } \\
\text { IL-2 } \\
\text { IL-6 } \\
\text { IL-8 } \\
\text { IL-17 } \\
\text { TNF- } \alpha \\
\text { IL-10 } \\
\text { IL-1 ra }\end{array}$ & $\begin{array}{l}\text { Present in distal airspaces of the lung } \\
\text { Associated with altered responsiveness in } \\
\text { Airway Smooth Muscle cells. }\end{array}$ & $\begin{array}{l}\text { Small Population size, limited number of } \\
\text { molecules focused } \\
\text { Not looking at the anti-inflammatory limb } \\
\text { of the cytokine cascade } \\
\text { Lack of serial measurements, including } \\
\text { ROC and cut-off values } \\
\text { No measurement of pro- or } \\
\text { anti-inflammatory cytokines provides a } \\
\text { useful tool in the diagnosis of ALI. }\end{array}$ & $\begin{array}{l}\text { McClintock et al., } \\
2008 \\
\text { Impellizzeri et al., } \\
2011\end{array}$ \\
\hline $\begin{array}{c}\text { Macrophage } \\
\text { chemoattractant } \\
\text { protein-1, MCP-1 }\end{array}$ & $\begin{array}{l}\text { Clinical significance of } \\
\text { MCP-1 levels in BAL and } \\
\text { serum in patients }\end{array}$ & $\begin{array}{c}\text { Negligible sample. } \\
\text { ROC curve analysis / cut-off values / No } \\
\text { correlation with radiological findings } \\
\text { No definitive relation with disease severity / } \\
\text { Influence by steroid treatment / Potential } \\
\text { influence by other lung disorders }\end{array}$ & $\begin{array}{l}\text { Ken-ichiro Inoue et } \\
\text { al., } 2006\end{array}$ \\
\hline $\begin{array}{c}\text { Macrophage } \\
\text { inflammatory } \\
\text { protein-1 } \alpha(\text { MIP-1 } \alpha)\end{array}$ & $\begin{array}{l}\text { MIP-1 serum levels } \\
\text { estimate the activity of } \\
\text { granuloma formation in } \\
\text { sarcoidosis }\end{array}$ & Insufficient sample & $\begin{array}{l}\text { Bergmeier et al., } \\
\quad 2007\end{array}$ \\
\hline $\begin{array}{l}\text { CXCL-11: CXC } \\
\text { chemokine } 11\end{array}$ & Abnormal increase & $\begin{array}{l}\text { Insufficient sample and no correlating } \\
\text { parameters }\end{array}$ & $\begin{array}{l}\text { Bergmeier et al., } \\
2007\end{array}$ \\
\hline $\begin{array}{c}\text { Markers of } \\
\text { endothelium activation/ } \\
\text { damage/Adhesion } \\
\text { molecules: } \\
\text { E, P, L-selectin } \\
\end{array}$ & $\begin{array}{l}\text { High expression in stimulated endothelial } \\
\text { cells. } \\
\text { Presence in serum potentially reflects the state } \\
\text { of endothelium in disease and the disease } \\
\text { severity in ALI. }\end{array}$ & $\begin{array}{l}\text { sE-selectin were not correlated with ARDS } \\
\text { development. } \\
\text { Low values of sL-selectin exhibited a } \\
\text { significant prognostic value. }\end{array}$ & Kayal et al., 1998 \\
\hline $\begin{array}{l}\text { I-CAM-1 } \\
\text { V-CAM-1 }\end{array}$ & $\begin{array}{c}\text { Sequential increase in levels of sICAM-1 in } \\
\text { plasma and circulation is suggestive of a strong } \\
\text { association between the severity of } \\
\text { hypotension shock }\end{array}$ & $\begin{array}{l}\text { Not found to be independent factor for } \\
\text { ARDS development. } \\
\text { Exhibited a considerable negative } \\
\text { predictive value for ARDS development. }\end{array}$ & Sessler et al, 1995. \\
\hline $\begin{array}{l}\text { ICAM-8, Plasminogen } \\
\text { activator } \\
\text { inhibitor-1(PAR1), } \\
\text { Protein C }\end{array}$ & Manipulates the coagulation system & $\begin{array}{l}\text { Indirectly related and Potential influence by } \\
\text { other lung disorders }\end{array}$ & $\begin{array}{l}\text { Bergmeier et al., } \\
\text { 2007; McClintock } \\
\text { et al., } 2008 \\
\text { Sokolova et al., } \\
2007, \\
\end{array}$ \\
\hline $\begin{array}{l}\text { von Willebrand factor } \\
\text { (VWF) }\end{array}$ & $\begin{array}{l}\text { Endothelial injury (as in ARDS) results in the } \\
\text { release of VWF from preformed stores into the } \\
\text { circulation by endothelial cells, platelets and } \\
\text { megakaryocytes }\end{array}$ & $\begin{array}{l}\text { An association between VWF and presence } \\
\text { or absence of sepsis, supporting the } \\
\text { hypothesis that ALI might be an } \\
\text { independent cause of systemic endothelial } \\
\text { activation and injury. No modulation of } \\
\text { plasma VWF concentrations by protective } \\
\text { mechanical ventilation is found }\end{array}$ & Ware et al., 2001 \\
\hline $\begin{array}{l}\text { TRP channels; } \\
\text { TRPVanilloid, } \\
\text { TRPAnkyrin, } \\
\text { TRPClassical, } \\
\text { TRPMelastatin }\end{array}$ & $\begin{array}{l}\text { Chemo-, Mechano-, and Thermosensitive. } \\
\text { Coupled to intracellular signaling pathways } \\
\text { and mediate heightened pain perception. } \\
\text { These can be the future promising biomarkers }\end{array}$ & $\begin{array}{l}\text { These receptors are sensitized by } \\
\text { proinflammatory agents }\end{array}$ & Geppetti et al., 2006 \\
\hline
\end{tabular}




\begin{tabular}{|c|c|c|c|}
\hline Factors & Description & Limitations & References \\
\hline $\begin{array}{c}\text { Lung } \\
\text { epithelium-specific } \\
\text { Proteins: } \\
\text { Type I epithelial } \\
\text { markers -RAGE } \\
\end{array}$ & $\begin{array}{l}\text { Receptor for advanced glycation end-products } \\
\text { (RAGE), } \\
\text { Epithelial injury }\end{array}$ & $\begin{array}{c}\text { Feeble correlations with CT features / } \\
\text { Inconclusive analysis of disease mortality / } \\
\text { Reproducibility issues / Small number of } \\
\text { patients }\end{array}$ & Uchida et al., 2006 \\
\hline $\begin{array}{l}\text { Surfactant protein D, } \\
\text { SP-D. a type } 2 \\
\text { epithelial cell markers } \\
\end{array}$ & $\begin{array}{c}\text { Elevated SPD levels associated with worse } \\
\text { clinical outcomes } \\
\text { Greater risk of death } \\
\end{array}$ & $\begin{array}{c}\text { Attenuation of SP-D plasma levels by lower } \\
\text { volume ventilation strategies }\end{array}$ & Eisner et al., 2003 \\
\hline $\begin{array}{l}\text { Mucin-associated } \\
\text { antigens; Krebs von } \\
\text { den Lungen (KL)-6 }\end{array}$ & $\begin{array}{l}\text { Detected in alveolar type II cells, epithelial } \\
\text { cells of the respiratory bronchioles. Also found } \\
\text { on other somatic cells (pancreatic cells, } \\
\text { eosophageal cells and fundic cells of the } \\
\text { stomach). KL-6 is proposed as a sensitive } \\
\text { indicator of damage to alveolar type II cells. Its } \\
\text { raise represents the destruction of the normal } \\
\text { lung parenchyma and architecture and the } \\
\text { increased permeability of the air-blood barrier }\end{array}$ & $\begin{array}{l}\text { Association of KL-6 serum levels with } \\
\text { variables of lung injury and severity with } \\
\text { mortality rates. } \\
\text { No statistically significant correlation was } \\
\text { found between blood levels and ventilation } \\
\text { strategies. } \\
\text { Non ILD-specific marker Potentially } \\
\text { influenced by malignancies / Small number } \\
\text { of patients }\end{array}$ & $\begin{array}{l}\text { Nathani et al., 2008; } \\
\text { Sato et al., } 2004\end{array}$ \\
\hline $\begin{array}{l}\text { CC16: Clara-cell } \\
\text { protein } 16\end{array}$ & $\begin{array}{l}\text { Generalized factor influencing and mediating } \\
\text { without conclusive evidence. }\end{array}$ & $\begin{array}{l}\text { No serial measurement / No ROC curve } \\
\text { analysis / cut-off levels Not definitive } \\
\text { cut-off values Low specificity and } \\
\text { sensitivity values / No adjustment with } \\
\text { disease severity } \\
\end{array}$ & Nuckton et al., 2002 \\
\hline $\begin{array}{l}\text { CK19: Cytokeratin } \\
\text { fragment } 19\end{array}$ & Elevated serum levels & Inconclusive and scope for further research & Nuckton et al., 2002 \\
\hline $\begin{array}{l}\text { Ca 19-9: Carbohydrate } \\
\text { antigen Sialyl Lewis (a) }\end{array}$ & $\begin{array}{l}\text { Serum levels as } \\
\text { markers of disease } \\
\text { activity in patients with } \\
\text { fibrosis lung disease } \\
\end{array}$ & $\begin{array}{l}\text { Not definitive cut-off values } \\
\text { Research gaps }\end{array}$ & Nuckton et al., 2002 \\
\hline $\begin{array}{l}\text { SLX: Carbohydrate } \\
\text { antigen Sialyl Lewis } \\
\text { (x) }\end{array}$ & $\begin{array}{cc}\text { Western blotting of } \\
\text { serum SLX may serve as } \\
\text { differentiator between } \\
\text { lung } & \text { diseases and adenocarcinoma } \\
\end{array}$ & Undistinguishable evidences & Nuckton et al., 2002 \\
\hline $\begin{array}{l}\text { Pulmonary dead space } \\
\text { fraction }\end{array}$ & Increase of abnormal fraction & Inconclusive evidence & Nuckton et al., 2002 \\
\hline $\begin{array}{l}\text { Extravascular lung } \\
\text { water }\end{array}$ & Abnormal increase of volume & multifactorial & Phillips et al., 2008 \\
\hline Pentraxin 3 (PTX3) & $\begin{array}{c}\text { Acute phase protein marker of severity } \\
\text { expressed locally in response to a variety of } \\
\text { infectious and inflammatory stimuli and plays } \\
\text { a key role in innate immunity. } \\
\text { Play role in the pathogenesis of ARDS. It can } \\
\text { be the promising factor for future }\end{array}$ & $\begin{array}{l}\text { Feasibility to bridge possible limitations in } \\
\text { applicable cases. }\end{array}$ & $\begin{array}{l}\text { Mauri et al., } 2008 \\
\text { He X and } \\
\text { Okutani et al. } \\
\text { (2007) }\end{array}$ \\
\hline $\begin{array}{l}\text { Matrilysin (matrix } \\
\text { metalloproteinase-MM } \\
\text { P-7), MMP-9 }\end{array}$ & $\begin{array}{l}\text { It was the most informative with increased } \\
\text { gene in their data set. } \\
\text { Post-operative day } 1 \text { plasma MMP-9 is } \\
\text { increased in patients with early lung injury. }\end{array}$ & $\begin{array}{l}\text { Association can be correlated in possible } \\
\text { cases. }\end{array}$ & Martin et al., 2005 \\
\hline $\begin{array}{l}\text { MBP: Major Basic } \\
\text { Protein, MCs: Mast } \\
\text { cells }\end{array}$ & Abundant expression of MBP in MCs & $\begin{array}{l}\text { The evidences need to be established by } \\
\text { increasing sample size. }\end{array}$ & Phillips et al., 2008 \\
\hline $\begin{array}{l}\text { Keratinocyte } \\
\text { chemoattractant }\end{array}$ & Elevated expression has been observed & $\begin{array}{l}\text { As a marker supportive evidences with } \\
\text { increased sample needs to be established. }\end{array}$ & $\begin{array}{l}\text { Ken-ichiro Inoue et } \\
\text { al., } 2006\end{array}$ \\
\hline $\begin{array}{l}\text { Transforming growth } \\
\text { factor- } \beta 1 \text { (TGF- } \beta 1 \text { ), }\end{array}$ & $\begin{array}{l}\text { Activation of latent TGF- } \beta \text { lead to upregulation } \\
\text { of MMP- } 12 \text {, } \\
\text { Contribute to genetic or acquired susceptibility } \\
\text { to diseases }\end{array}$ & Multi-dependent & Morris et al., 2003 \\
\hline CD14 & $\begin{array}{l}\text { Recognition and binding of a variety of (myco) } \\
\text { bacterial and viral components in the lung. }\end{array}$ & $\begin{array}{l}\text { Amplification of host responses to various } \\
\text { biological infections }\end{array}$ & $\begin{array}{l}\text { Adam Anas et al., } \\
2010\end{array}$ \\
\hline Human Thy-1 (CD90), & $\begin{array}{c}\text { Mediate adhesion of inflammatory cells to } \\
\text { activated microvascular endothelial cells via } \\
\text { interaction with Mac-1 (CD11b/CD18) in } \\
\text { vitro. }\end{array}$ & $\begin{array}{l}\text { Less sample size and need for further } \\
\text { studies }\end{array}$ & $\begin{array}{l}\text { Schubert et al., } \\
2011\end{array}$ \\
\hline
\end{tabular}




\begin{tabular}{|c|c|c|c|}
\hline Factors & Description & Limitations & References \\
\hline $\begin{array}{c}\text { Mitogen activated } \\
\text { protein kinase (MAPK) } \\
\text { activation }\end{array}$ & Its level increases & Indirectly related & Hansell et al., 2003 \\
\hline $\begin{array}{c}\text { Poly-ADP-ribosyl } \\
\text { polymerase (PARP) }\end{array}$ & $\begin{array}{c}\text { Profound Expressivity can be a future } \\
\text { biomarker if studied in depth. }\end{array}$ & $\begin{array}{c}\text { Peripheral observations need to probed in } \\
\text { depth with significant sample size. }\end{array}$ & $\begin{array}{c}\text { Hansell et al,2003 } \\
\text { Knottnerus et al., } \\
2002\end{array}$ \\
\hline $\begin{array}{c}\text { Nuclear factor-kB } \\
\text { NF-kB) inducible } \\
\text { nitric oxide synthase } \\
\text { (iNOS) }\end{array}$ & $\begin{array}{c}\text { Induces response related to inflammatory } \\
\text { mediators such as interferons. }\end{array}$ & May be correlated with other impressive \\
factors also. & $\begin{array}{c}\text { Knottnerus et al., } \\
2002 ; \text { Hansell et al., } \\
2003\end{array}$ \\
\hline $\begin{array}{c}\text { Peroxisome } \\
\text { proliferator activated } \\
\text { receptors (PPARs) }\end{array}$ & $\begin{array}{c}\text { ligand-activated transcription factors with } \\
\text { three isoforms, designated as PPAR } \alpha \\
\text { (NR1C1), PPAR } \beta \text { (PPAR } \delta \text { NR1C2), and } \\
\text { PPAR } \gamma \text { (NR1C3).Also a future biomarker. }\end{array}$ & $\begin{array}{c}\text { Diversified response mechanisms which } \\
\text { need to be probed for unidirectional } \\
\text { linkages. }\end{array}$ & $\begin{array}{c}\text { Reynders et al., } \\
2006 \\
\text { Arnold et al., 2006. }\end{array}$ \\
\hline
\end{tabular}

\subsection{Cellular, Molecular Immune Responses}

Platelets have molecular systems and functional activities that link hemostasis and inflammation. Platelets and the lung-a complex multicellular organ that accomplishes gas exchange, immune surveillance, and other physiologic processes-have interrelated activities. Inflammatory diseases and other pulmonary disorders cause accumulation of platelets in the lung, and remote tissue injury and systemic conditions such as sepsis can activate platelets in the circulation and cause them to sequester in pulmonary vascular beds. Activated platelets release paracrine mediators that can alter pulmonary function in a variety of ways. These adhesion and signalling molecules allow platelets to interact not only with pulmonary endothelium and, potentially, other resident lung cells, but also with one another and with leukocytes in pulmonary vessels. Adherent, activated platelets deposited on exposed vascular matrix provide a surface for rolling and attachment of myeloid leukocytes in experimental studies[26]. Platelet depletion reduced PMN accumulation in microvascular, interstitial, and alveolar compartments, an experimental finding with potential clinical correlates, since adhesive ness polymorpho nuclear leukocytes (PMNs) of was related to platelet numbers in pulmonary blood samples from patients with ARDS. PMNs activated by platelets and/or by other signalling pathways after being locally recruited by platelets have potent mechanisms that can increase vascular permeability and injure endothelial and epithelial cells. Platelet-directed progenitor cell recruitment may drive vascular injury in addition to mediating vascular repair and development. Platelet signalling is reported to direct progenitor cells along differentiation pathways that lead to foam cell formation under some conditions[57]. Foam cell formation is considered to be a maladaptive response in atherosclerosis. Unfortunately, the mechanical stress produced by excessive mechanical ventilation, is now recognized as an additional key contributor to lung inflammation and a vital determinant of lung injury. Matrix metalloproteinase-8 (MMP-82, collagenase-2, neutrophil collagenase) is a member of the interstitial collagenase subgroup of the MMP family of zinc-dependent, neutral proteinases. MMP-8 has novel roles in restraining lung inflammation and in limiting alveolar capillary barrier injury during ALI in mice by inactivating MIP- $1 \alpha[58]$. In addition, membrane-bound MMP-8 on activated lung PMNs is likely to be the key bioactive form of the enzyme that limits lung inflammation and alveolar capillary barrier injury during ALI. Pablo et al in 2010 identified MMP-8 as a PMN-derived proteinase that plays a significant role in regulating lung inflammation, alveolar capillary barrier injury, and mortality during ALI in mice by cleaving and inactivating a $\mathrm{CC}$ chemokine[58]. However, the additional predictive value of the plasma biomarkers added to the clinical predictors alone was modest; thus, further work will be needed to test the value of these biomarkers over clinical predictors alone, suggesting that important contributors to mortality may not have been accounted for by the model[59]. An alternative approach to examining clinical samples is to test the validity of existing or novel candidate biomarkers using models systems, in which the signal-to-noise ratio is likely to be more favourable and the time course of the biomarker's response can be more precisely determined. One-lung ventilation may be a useful model of VALI because it is associated with a smaller lung volume available for ventilation, localized lung collapse or atelectasis and impaired oxygenation, resulting in exposure of the ventilated lung to volutrauma, repeated opening of collapsed airspaces (atelectotrauma), and a high inspired oxygen concentration. While, in the clinical setting the effect on exhaled breath condensate $\mathrm{pH}$ of changing ventilator settings may be drowned by "noise" from co-incident inflammatory processes in the lung, it may hold promise as a non-invasive real-time biomarker of VALI, despite the fact that the mechanism by which exhaled breath condensate acidification is poorly understood.

\subsection{PPAR, TRP Channels, PAR1 and Proteomics}

Peroxisome proliferators activated receptors (PPARs) are ligand-activated transcription factors that have recently been implicated as targets for the regulation of inflammation. PPARs are members of the nuclear hormone receptor family with three isoforms, designated PPAR $\alpha$ (NR1C1), PPAR $\beta$ 
(PPAR $\delta$, NR1C2), and PPAR $\gamma(\mathrm{NR} 1 \mathrm{C} 3)$. Activation of these receptors has been shown to regulate diverse cellular responses including production of immunomodulatory cytokines, chemotaxis, cell differentiation, proliferation, and survival. Recent evidence supports a role for PPARs in the regulation of lung inflammation. Differential expression of PPAR isoforms has been demonstrated in different inflammatory, resident, and structural cells in the airways. Both PPAR $\alpha$ and PPAR $\gamma$ are expressed in macrophages and monocytes, eosinophils, with PPAR $\beta$ also expressed in neutrophils[46]. Dendritic cells express PPAR $\gamma$ but not PPAR $\alpha$, but both PPAR $\alpha$ and PPAR $\gamma$ are expressed in B and T lymphocytes[60]. PPAR $\beta$ and PPAR $\gamma$ but not PPAR $\alpha$ are expressed in mast cells, while all three isoforms have been detected in A549 and BEAS-2B airway epithelial cell lines[47]. Mesenchymal expression of PPARs has been demonstrated with PPAR $\gamma$ detected in primary fibroblasts[61], and with PPAR $\alpha$ and PPAR $\gamma$ but not PPAR $\beta$ in airway smooth muscle. Although ovalbumin sensitization has been shown to increase PPAR $\gamma$ expression in the lung, levels of PPAR $\alpha$ were decreased in inflamed lungs of allergen -exposed mice[62]. It is important therefore to define receptor-mediated responses at both the cellular level and in integrated animal models of disease to elucidate the role for PPARs in lung inflammation. Specific ablation of PPAR $\gamma$ in the airway epithelium suggests that PPAR $\gamma$ has a role in the epithelial-mesenchymal interactions necessary for the establishment of normal lung structure[63]. The implications of this finding on inflammation in lung disease have yet to be explored. TRP Channels are chemo, mechano, and thermo sensitive and coupled to intracellular signaling pathways and mediate heightened pain perception. They are classified into four types as TRPVanilloid, TRPClassical, TRPMelastatin, TRPAnkyrin based on the availability of the protein types. These can be the future promising biomarkers as they are sensitized by proinflammatory agents who can limit the contribution and diagnosis[31]. Plasminogen activator inhibitor-1(PAR1) expression is up-regulated in response to a number of pro-inflammatory and profibrotic mediators[29], but the mediators responsible for controlling PAR1 expression in the fibrotic lung are currently unknown. The clearest physiological role for PAR1 is in the activation of platelets by thrombin, one of the key events involved in blood clotting. In addition, PAR1 plays a central role in influencing a number of cellular responses that are central to the subsequent inflammatory and tissue repair programmes initiated following tissue injury. This receptor is currently a major drug target in the setting of thrombosis and cardiovascular disease[64]. A recent report that autocrine production of Cyclo-oxygenase-2 (COX-2)-derived PGE2 is responsible for down regulating the expression of PARs (PAR1-PAR3) following PAR1 activation in cultured human lung fibroblasts is of particular interest in view of the compelling evidence that fibroblasts from patients with IPF are unable to up regulate $\mathrm{COX}-2$ gene expression in response to various pro-inflammatory and pro-fibrotic stimuli. This may provide a plausible explanation for the high levels of
PAR1 expression on these cells in IPF and further supports the notion that uncontrolled PAR1 signaling may be of pathological significance in this disease setting.

ALI mechanisms is mediated by release of granular enzymes or oxygen radicals by neutrophils, aggregation of neutrophils, monocytes and platelets, and activation of the clotting cascade use constitutive biochemical pathways and do not require induction of new transcripts or expression of new proteins. In addition, transcript profusion does not clearly reflect abundance of corresponding proteins or the physiological results. Critical messenger RNAs are under strict posttranscriptional control in many cases. Constitutively expressed but repressed messenger RNAs can be translated to proteins in response to cellular signals that are pertinent to ALI/ARDS and its systemic manifestations [65]. Thus, studies of acute constitutive cellular and functional responses should not be discarded in wholesale fashion but should be used in a complementary fashion with gene analysis strategies and with the use of engineered recombinant proteins for the management of disease without any side effects. Growing proteomic technologies have the potential to recognize each protein expressed in isolated cells or in complex tissues such as injured lung and also to determine posttranslational modifications, protein-protein interactions, and other critical features that define phenotype and regulate cellular function[66]. Proteomic approaches can provide physiologic relevance that is not inherent in measuring transcript levels and profiles[67]. New proteomic strategies based on isotope-coded affinity tags can accurately quantify individual proteins in complex mixtures, a capability that has been lacking in the past, and can also provide sequence information linking descriptive and quantitative proteomics[66]. Proteomic analysis of clinical samples may be useful in establishing molecular patterns that are characteristic of individual diseases or disease stages[68]. The most effective use of proteomic strategies, as with genomic and protein engineering technology will be in combination with traditional approaches to determine the functions of key proteins and their effects on cell and tissue behavior at molecular level is possible[69,70]. In several cases these experimental strategies will need background preparation of new reagents, databases, and bioinformatic tools to handle large amounts of complex data[66, 71, 72].

\subsection{Environmental Factors and Heterogeneity of Phenotype in ALI}

A major gap in our knowledge is the extent to which genetic features interact with environmental variables to influence susceptibility to ALI/ARDS. Patients extends pneumonia from numerous diverse etiologies, including gram-positive or gram-negative bacteria, viruses, or even fungi orparasites, particularly in the existence of immunosuppression, and the signaling pathways that control the inflammatory response to any particular organism depends on the initial molecular interactions between the host cells and the organism[73]. A better consideration of bacterial genetics and the specific virulence factors of 
infecting bacteria should provide new approaches for understanding susceptibility to pneumonia and ALI/ARDS both as a cause of injury and as a cause of nosocomial pneumonia in patients with ALI/ARDS[74]. In most cases, susceptibility to ALI/ARDS, and the natural history of this condition once it is established, is likely governed by genetic features together with environmental variables in the complex fashion.

In Mendelian diseases, a mutation in one or both alleles of a single disease gene leads to a pathologicphenotype, whereas complex genetic syndromes are generally caused by mutations in more than one gene with significant contributions from the environment usually influencing the manifestations of the disease. Additional features of complex genetic diseases include large phenotypic variation, incomplete penetrance, late age of onset, the potential for locus heterogeneity, and lack of easily identified large families because of a complicated pattern of heritability. Complex human disorders may also result from multiple rare variant mutations in a single gene leading to similar or identical phenotypes. Finally, many traits of clinical significance in complex diseases have continuous variation rather than discrete phenotypes; interacting genes that influence variation in these traits are located in chromosomal regions termed quantitative trait loci[75]. The heterogeneity of inciting factors and outcomes in ALI/ARDS creates complexity and uncertainty in the study of this syndrome, in particularly confounding problem in establishing genetic and environmental contributions to complex diseases. Identification and establishment of new approaches for dissecting interactions between genes and environment involving epidemiologic studies of carefully characterized populations likely provide accelerated insight into multi-factorial syndromes such as ALI/ARDS and new approaches[76]. In order to better understand specific mechanisms of ALI under different clinical conditions as well as to probe genetic and environmental influences, it is important that more information be obtained regarding characterization of subgroups of patients with ALI/ARDS.

\subsection{Possible Future Treatments}

In spite of analysing samples from large well-designed trials, there is no biomarker in current use that positively identifies patients with the classical histopathological appearances of diffuse alveolar damage, that predicts a poor outcome or that specifically identifies a pathological process[77]. Biomarkers potentially combined with physiological and genomic data should be used to identify patient groups for research studies and individuals who are most likely to gain from targeted therapies. Therapeutic agents aimed at blunting excessive procoagulant activity and signalling may therefore offer promise as novel therapeutic agents in these disease settings. Targeting the lung epithelium directly with novel inhaled therapies may offer advantage over traditional anticoagulant therapy in terms of avoidance of potential bleeding complications.
Moreover, therapeutic strategies aimed at targeting PAR1 directly may offer similar benefits. As noted above, WBB6F1-KitW/W-v mice have other defects besides a profound deficiency of mast cells, including neutrophil defects, and mast cell activators can have effects on cell types other than mast cells. However, from a clinical perspective, if this novel vaccination approach can be shown to be effective and, as importantly, safe (since mast cell activation in the context of vaccination could result in clinical toxicities), this approach may be of considerable value even if the method works because of effects on cells in addition to (or other than) mast cells[78].

\section{Conclusions}

Future investigations, technical improvements and introduction of novel non invasive markers are warranted in order to elevate the association of serum biomarkers with the pathogenesis of acute lung inflammatory disease in the same status as for tumour markers with lung cancer. Nonetheless, crossing the boundary from research to clinical application requires validation in multiple settings, experimental evidence supporting a pathophysiologic role, and ideal intervention trials showing the modification improves the experimental evidences and helps in making patient-centered decisions. The emergence of pioneering technologies including DNA, Protein, and tissue microarrays which have already been applied with great success in the respiratory research field can help scientists to circumvent this problem and bridge this boundary at cellular level[69,70, 72]. Recent achievements in the treatment of critically ill patients offered an excellent opportunity for rapid progress, as do new and evolving biologic, genomic, proteomic and genetic approaches. Moreover, Protein engineering is replacing all old technologies, emerging as biochemically and clinically promising proteomic tool for future hopes to provide support in detection of essential genetic or proteomic factors influencing the development, severity and time course of development and resolution of ALI/ARDS as well as the development of multiple organ failure, uncontrolled cellular activities, management and other systemic sequelae. Expansion of protein engineering and resources specifically relevant to ALI/ARDS, triggering conditions, and systemic manifestations will likely facilitate characterization of interactions (protein-ligand interactions, DNA-protein interactions, RNA-protein interactions andDNA-RNA-prot ein interactions) between genetic and environmental variables that influence ALI. Engineering of active site of receptors and interacting lingand will help in specifically targeting the disease and can be used as a promising tool in the diagnosis. Biomarker development for patients with ALI is an essential component of progress in translational medicine, but Alastair et al have highlighted potential drawbacks in the way of biomarker translational medicine like the heterogeneity of cases (ALI is a condition resulting 
from many causes of acute lung failure), large iatrogenic role of pathogenesis requiring standardized conditions, gas exchange surface of the lung relatively out-of-the-way to investigation and indispensablecomplicat-ing the pathogenic process[79]. The timeframes of the condition are short, such that windows for intervention may close in the time that it takes to analyse samples and processing the data. It is important to note that the greatest promise is in only few (VWF, IL-1 $\beta$, IL-6, ICAM-1, VCAM-I, E-selectin, TRP channels, PAR1 and PPAR) which exhibited independent discriminatory power and specifically targets of protein engineering. Inturn, these markers can be quite useful to supplement the clinical, radiological and physiological monitoring of the disease and identify high risk patients who would benefit fromaggressi-ve management of established risk factors. Even though they do not necessarily need to reflect pathogenic processes in supportive to the inflammation. At the same time biomarkers do not have a major role in the management of ALI and the development of novel therapies, but it can be made possible in near future with use of protein engineering and it is even likely that biomarkers will be developed that help in targeting an increasing range of disease modifying therapies in the future. Combining all these properties at various levels of biomarkers including physiological, cellular, molecular and biochemical evidences and other data may add predictive power in detection of inflammation, will further stimulate the development of important aids to research and therapy. Genetically altered mouse models will also be useful. Lung-and tissue-specific conditional knockouts, overexpression of candidate genes, and other genetic models should be of value in dissecting the host response to pathological conditions that model human lung injury. In addition research is needed to evaluate products of endothelial injury as well as mechanisms that reflect endothelial, neutrophil, and thrombotic interactions. Markers of endothelial injury such as von Willebrand factor that reflect pulmonary and systemic endothelial injury may prove useful. Further basic research is needed to detail the cellular, molecular, and physiologic mechanisms that protect the lung from biomechanical stress and injury and potentially modulate systemic inflammation. Other studies are needed to explore the role of the inflammatory and coagulation pathways in inducing organ injury in sepsis and other injury states and in modulating ALI. The potential for enhancement of lung repair with engineered protein or peptides should be explored. Investigations and collaborative efforts that include cellular and mechanistic studies combined with animal and clinical studies will be the key to improving detection and treatment of this complex syndrome. Case-control relationship studies, though of less validity, might be useful[80]. Irrespective of the method that a laboratory chooses to implement (i.e., conventional or a molecular method) for the detection of ALI, institutions needs to determine the best fit for their setting on the basis of their patient population, response and resources. Whether it is ALI or other emerging malignant diseases, the clinical community has always responded to these challenges. More evidence based studies of increasing scientific methodologi es pointing to holistic approach that focus on patient outcomes, cost-effectiveness, and method of accuracy over time are needed.

\section{Abbreviation}

ARDS, acute respiratory distress syndrome; ALI, acute lung injury; CCL2, chemokine; TGFb, transforming growth factor-beta; PAR ; Plasminogen activator inhibitor-1; COX-2: Cyclo-oxygenase-2; MCP-1: Monocyte chemotacti c protein-1; MIP-2: Macrophage inflammatory protein-2;

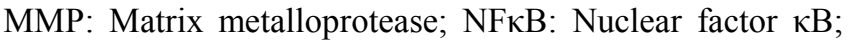
OVA: Ovalbumin; PPAR: Peroxisome proliferator activated receptor; $\mathrm{TNF} \alpha$ : Tumour necrosis factora; BAL; Bronchoalveolar lavage; Ca 19-9; Carbohydrate antigen sialyl Lewis a; CC16; Clara Cell Protein; CK19; Cytokeratin fragment 19; SP; Surfactant protein ; KL-6; Krebs von den Lungen; HRCT; High resolution computed tomography; PFT; Pulmonary Function Test; IL-1 $\beta$; interleukin-1 $\beta$; NIH-National Institute of Health; ICAM- Intracellular adhesion molecules; ITAC: Interferon-inducible $\mathrm{T}$ cell-a chemoattractant; sIL-2R: soluble interleukin-2 receptor; ROC: Receiver Operating Characteristic; SP: Surfactant Protein; MCP-1: Monocyte Chemoattractant; Protein-1; MIP-1a: Monocyte Inflammatory Protein-1a; TRPchannelTransient receptor potential channel; ICAM-8-Intercellular Adhesion Molecule 8; VCAM-1-Vascular cell adhesion protein 1 .

\section{ACKNOWLEDGEMENTS}

We acknowledge the immense help received from the scholars whose articles are cited and included in references of this review article. The contributors of this article are also grateful to authors / editors / publishers of all those articles, journals and books from where the literature for this article has been snowballed, reviewed, incorporated and discussed in this current review article. We are also grateful to UGC, government of India for research funding.

\section{Disclosures}

The authors have no conflicts of interest to disclose.

\section{REFERENCES}

[1] Biomarkers Definitions Working Group. Biomarkers and surrogate endpoints: preferred definitions and conceptual framework. Clin Pharmacol Ther 2001: 69; 89-95.

[2] Proudfoot AG, McAuley DF, Hind M, Griffiths MJ. Translational research: what does it mean, what has it delivered and what might it deliver? Curr Opin Crit Care 2011; 17:495-503. 
[3] Manolio T. Novel risk markers and clinical practice. N Engl J Med 2003; 349: 1587-9.

[4] Hansell DM, Wells AU. Towards complete and accurate reporting of studies of diagnostic accuracy: the STARD initiative. Clin Radiol 2003; 58: 573-4.

[5] Bouadma L, Luyt CE, Tubach F, Cracco C, Alvarez A, Schwebel C, Schortgen F, Lasocki S, Veber B, Dehoux M, Bernard M, Pasquet B, Regnier B, Brun- Buisson C, Chastre J, Wolff M. Use of procalcitonin to reduce patients' exposure to antibiotics in intensive care units (PRORATA trial): a multicentre randomised controlled trial. Lancet 2010; $375: 463-474$

[6] Karlsson S, Heikkinen M, Pettila V, Alila S, Vaisanen S, Pulkki K, Kolho E, Ruokonen E. Predictive value of procalcitonin decrease in patients with severe sepsis: a prospective observational study. Crit Care 2010; 14: R205.

[7] Luyt CE, Combes A, Trouillet JL, Chastre J. Value of the serum procalcitonin level to guide antimicrobial therapy for patients with ventilator-associated pneumonia. Semin Respir Crit Care Med 2011; 32:181-187.

[8] Whitsett J, Bachurski C, Barnes K, Bunn P Jr, Case L, Cook D, Crooks D, Duncan MW, Dwyer-Nield L, Elston RC, et al. Functional genomics of lung disease. Am J Respir Cell Mol Biol 2004; 31: S23-S34.

[9] Rubenfeld G D, Caldwell E, Peabody E, Weaver J, Martin D P, Neff M, Stern E J, Hudson L D. Incidence and outcomes of acute lung injury. N Engl J Med 2005; 353: 1685-1693.

[10] Frutos-Vivar F, Nin N, Esteban A. Epidemiology of acute lung injury and acute respiratory distress syndrome. Curr Opin Crit Care 2004; 10:1-6.

[11] Bhadade RR, de Souza RA, Harde MJ, Khot A. Clinical characteristics and outcomes of patients with acute lung injury and ARDS. J Postgrad Med 2011; 57(4): 286-90.

[12] Vigg A, Mantri S. Clinical profile of ARDS. J Assoc Physicians India 2003: 51; 855-8

[13] Bajpai S, Bichile L. Mortality analysis of patients of acute febrile illness during monsoon in a tertiary care hospital of Mumbai. Infect Dis Clin Pract 2008; 16: 294-7.

[14] Bonfield TL, Panuska JR, Konstan MW, Hilliard KA, Hilliard JB, Ghnaim H, Berger M. Inflammatory cytokines in cystic fibrosis lungs. Am J Respir Crit Care Med 1995; 152: 2111-2118.

[15] Wheeler AP, Bernard GR. Acute lung injury and the acute respiratory distress syndrome: a clinical review. Lancet 2007 ; 369:1553-1564.

[16] Ashbaugh DG, Bigelow DB, Petty TL, et al. Acute respiratory distress in adults. Lancet 1967; 2:319-323.

[17] Gattinoni L, Pesenti A. The concept of "baby lung." Intensive Care Med 2005; 31: 776-784.

[18] Crosby LM, Waters CM. Epithelial repair mechanisms in the lung. Am J Physiol Lung Cell Mol Physiol 2010; 298: L715-731.

[19] Christie JD, Ma SF, Aplenc R, Li M, Lanken PN, Shah CV, Fuchs B, Albelda SM, Flores C, Garcia JG. Variation in the myosin light chain kinase gene is associated with development of acute lung injury after major trauma. Crit Care Med 2008; 36: 2794-2800.

[20] Rocco PR, Zin WA. Pulmonary and extrapulmonary acute respiratory distress syndrome: are they different? Curr Opin Crit Care 2005; 11: 10-17.

[21] Strieter RM, Starko KM, Enelow RI, Noth I, Valentine VG. Idiopathic Pulmonary Fibrosis Biomarkers Study Group. Effects of interferon-gamma $1 \mathrm{~b}$ on biomarker expression in patients with idiopathic pulmonary fibrosis. Am J Respir Crit Care Med 2004; 170: 133-40.

[22] Rothkrantz-Kos S, van Dieijen-Visser MP, Mulder PG, Drent M. Potential usefulness of inflammatory markers to monitor respiratory functional impairment in sarcoidosis. Clin Chem 2003; 49:1510-7.

[23] McClintock D, Zhuo H, Wickersham N, Matthay MA, Ware LB. Biomarkers of inflammation, coagulation and fibrinolysis predict mortality in acute lung injury. Crit Care 2008: 12; R41.

[24] Impellizzeri D, Esposito E, Mazzon E, Paterniti I, Di Paola R, Bramanti P, Cuzzocrea S. Effect of apocynin, a NADPH oxidase inhibitor, on acute lung inflammation. Biochem Pharmacol 2011: 81(5); 636-48.

[25] Ken-ichiro Inoue, Hirohisa Takano, Rie Yanagisawa, Seishiro Hirano, Miho Sakurai, Akinori Shimada, and Toshikazu Yoshikawa. Effects of Airway Exposure to Nanoparticles on Lung Inflammation Induced by Bacterial Endotoxin in Mice. Environ Health Perspect 2006: 114; 1325-1330.

[26] Bergmeier W, Wagner DD. Inflammation. In: Michaelson AD, editor. Platelets. Boston: Academic Press, 2007, pp. 713-726.

[27] Kayal S, Jais JP, Aguini N, et al. Elevated circulating E-selectin, intercellular adhesion molecule 1, and von Willebrand factor in patients with severe infection. Am J Respir Crit Care Med 1998: 157; 776-84.

[28] Sessler CN, Windsor AC, Schwartz M, et al. Circulating ICAM-1 is increased in septic shock. Am J Respir Crit Care Med 1995:151;1420-7

[29] Sokolova E, Reiser G. A novel therapeutic target in various lung diseases: airway proteases and protease-activated receptors. Pharmacol Ther 2007:115; 70-83.

[30] Ware LB, Conner ER, Matthay MA. von Willebrand factor antigen is an independent marker of poor outcome in patients with early acute lung injury. Crit Care Med 2001: 29; 2325-2331.

[31] Geppetti, P., Materazzi, S., Nicoletti, P. The transient receptor potential vanilloid 1: role in airway inflammation and disease. Eur. J. Pharmacol 2006: 533; 207-214.

[32] Uchida T, Shirasawa M, Ware LB, Kojima K, Hata Y, Makita K, Mednick G, Matthay ZA, Matthay MA. Receptor for advanced glycation end-products is a marker of type I cell injury in acute lung injury. Am J Respir Crit Care Med 2006: $173 ; 1008-1015$.

[33] Eisner MD, Parsons P, Matthay MA, Ware L, Greene K. Plasma surfactant protein levels and clinical outcomes in patients with acute lung injury. Thorax 2003: 58; 983-988. 
[34] Nathani N, Perkins GD, Tunnicliffe W, Murphy N, Manji M, Thickett DR. KL-6 is a marker of alveolar inflammation but not infection in patients with ARDS. Crit Care 2008: 12; R12.

[35] Sato H, Callister MEJ, Mumby S, Quinlan GJ, Welsh KI, duBois RM, Evans TW. KL-6 levels are elevated in plasma from patients with acute respiratory distress syndrome. Eur Respir J 2004: 23; 142-145.

[36] Nuckton TJ, Alonso JA, Kallet RH, Daniel BM, Pittet JF, Eisner MD, Matthay MA. Pulmonary dead-space fraction as a risk factor for death in the acute respiratory distress syndrome. N Engl J Med 2002: 346; 1281-1286.

[37] Phillips CR, Chesnutt MS, Smith SM. Extravascular lung water in sepsis-associated acute respiratory distress syndrome: indexing with predicted body weight improves correlation with severity of illness and survival. Crit Care Med 2008: 36; 69-73.

[38] Mauri T, Coppadoro A, Bellani G, Bombino M, Patroniti N, et al. Pentraxin 3 in acute respiratory distress syndrome: an early marker of severity. Crit Care Med 2008: 36; 2302-8.

[39] He X, Han B, Liu M. Long pentraxin 3 in pulmonary infection and acute lung injury. Am J Physiol Lung Cell Mol Physiol 2007: 292; L1039-L1049.

[40] Okutani D, Han B, Mura M, Waddell TK, Keshavjee S, Liu M. High-volume ventilation induces pentraxin 3 expression in multiple acute lung injury models in rats. Am J Physiol Lung Cell Mol Physiol 2007: 292; L144-L153.

[41] Martin GS, Eaton S, Mealer M, Moss M. Extravascular lung water in patients with severe sepsis: a prospective cohort study. Crit Care 2005: 9; R74-R82.

[42] Morris DG, Huang X, Kaminski N, Wang Y, Shapiro SD, Dolganov G, Glick A, Sheppard D. Loss of integrin alpha (v) beta6-mediated TGF-beta activation causes Mmp12-dependent emphysema. Nature 2003: 422; 169-73.

[43] Adam Anas, Tom van der Poll, Alex F de Vos. Role of CD14 in lung inflammation and infection. Crit Care 2010: 14(2); 209.

[44] Schubert K, Polte T, Bönisch U, Schader S, Holtappels R, Hildebrandt G, Lehmann J, Simon JC, Anderegg U, Saalbach A. Thy-1 (CD90) regulates the extravasation of leukocytes during inflammation.Eur J Immunol 2011: 41(3);645-56.

[45] Knottnerus JA, van Weel C, Muris JW. Evaluation of diagnostic procedures. BMJ 2002: 324; 477-80.

[46] V. Reynders, S. Loitsch, C. Steinhauer, T. Wagner, D. Steinhilber, and J. Bargon. Peroxisome proliferator-activated receptor $\alpha$ (PPAR $\alpha)$ down-regulation in cystic fibrosis lymphocytes. Respiratory Research 2006: 7; 104.

[47] R. Arnold and W. K“onig. Peroxisome-proliferator-activated receptor- $\gamma$ agonists inhibit the release of proinflammatory cytokines from RSV-infected epithelial cells. Virology 2006:346(2); 427-439.

[48] Rojas M, Woods CR, Mora AL, Xu J, Brigham KL. Endotoxin-induced lung injury in mice: structural, functional, and biochemical responses. Am J Physiol Lung Cell Mol Physiol 2005; 288: L333-L341.

[49] Nakae S, Suto H, Berry GJ, Galli SJ. Mast cell-derived TNF can promote Th17 cell-dependent neutrophil recruitment in ovalbumin-challenged OTII mice. Blood 2007; 109:3640-8.
[50] Tremblay L, Valenza F, Ribeiro SP, et al. Injurious ventilator strategies increase cytokines and c-fos m-RNA expression in an isolated rat lung model. J Clin Invest 1997; 99:944-952.

[51] von Bethmann AN, Brasch F, Nusing R, et al. Hyperventilation induces release of cytokines from perfused mouse lung. Am J Respir Crit Care Med 1998; 157: 263-272.

[52] Calfee CS, Eisner MD, Parsons PE, Thompson BT, Conner ER Jr, Matthay MA, Ware LB. Soluble intercellular adhesion molecule-1 and clinical outcomes in patients with acute lung injury. Intensive Care Med 2009; 35:248-257.

[53] Frank JA, Parsons PE, Matthay MA. Pathogenetic significance of biological markers of ventilator-associated lung injury in experimental and clinical studies. Chest 2006: 130; 1906-1914.

[54] Calfee CS, Ware LB, Eisner MD, Parsons PE, Thompson BT, Wickersham N, Matthay MA. NHLBI ARDS Network: Plasma receptor for advanced glycation end-products and clinical outcomes in acute lung injury. Thorax 2008: 63; 1083-1089.

[55] Rogier M Determann, Annick ANM Royakkers, Jack J Haitsma, Haibo Zhang, Arthur S Slutsky, V Marco Ranieri, Marcus J Schultz. Plasma levels of surfactant protein D and KL-6 for evaluation of lung injury in critically ill mechanically ventilated patients. BMC Pulmonary Medicine 2010 10:6.

[56] Ware LB, Matthay MA, Parsons PE, Thompson BT, Januzzi $\mathrm{JL}$, Eisner MD. Pathogenetic and prognostic significance of altered coagulation and fibrinolysis in acute lung injury/acute respiratory distress syndrome. Crit Care Med 2007: 35; $1821-1828$

[57] Stellos K, Gnerlich S, Kraemer B, Lindemann S, Gawaz M. Platelet interaction with progenitor cells: vascular regeneration or injury? Pharmacol Rep 2008): 60; 101-108.

[58] Pablo A. Quintero, Martin D. Knolle, Luisa F. Cala, Yuehong Zhuang, and Caroline A. Owen. Matrix Metalloproteinase-8 Inactivates Macrophage Inflammatory Protein- $1 \alpha$ to Reduce Acute Lung Inflammation and Injury in Mice J Immunol 2010):184(3); 1575-1588.

[59] Calfee CS, Ware LB, Glidden DV, Eisner MD, Parsons PE, Thompson BT, Matthay MA. National Heart, Blood, and Lung Institute Acute Respiratory Distress Syndrome Network: Use of risk reclassification with multiple biomarkers improves mortality prediction in acute lung injury. Crit Care Med 2011:39; 711-717.

[60] D. C. Jones, X. Ding, and R. A. Daynes. Nuclear receptor peroxisome proliferator-activated receptor $\alpha(\operatorname{PPAR} \alpha)$ is expressed in restingmurine lymphocytes. The PPAR $\alpha$ in $T$ and B lymphocytes is both transactivation and transrepression competent," Journal of Biological Chemistry 2002: 277(9); $6838-6845$

[61] H. A. Burgess, L. E. Daugherty, T. H. Thatcher, et al. PPAR $\gamma$ agonists inhibit TGF- $\beta$ induced pulmonary myofibroblast differentiation and collagen production: implications for therapy of lung fibrosis. American Journal of Physiology 2005: 288(632-6); L1146-L1153.

[62] J. Becker, C. Delayre-Orthez, N. Frossard, and F. Pons. Regulation of inflammation by PPARs: a future approach to 
treat lung inflammatory diseases? Fundamental and Clinical Pharmacology 2006: 20(5);429-447.

[63] D. M. Simon, M. C. Arikan, S. Srisuma, et al. Epithelial cell PPAR $\gamma$ contributes to normal lung maturation. The FASEB Journal 2006: 20(9);1507-1509.

[64] Chackalamannil S. Thrombin receptor (protease activated receptor-1) antagonists as potent antithrombotic agents with strong antiplatelet effects. J Med Chem 2006:49; 5390-5403.

[65] Mahoney TS, Weyrich AS, Dixon DA, McIntyre T, Prescott SM, Zimmerman GA. Cell adhesion regulates gene expression at translational checkpoints in human myeloid leukocytes. Proc Natl Acad Sci USA 2001: 98; 10284-10289.

[66] Gygi SP, Aebersold R. Mass spectrometry and proteomics. Curr Opin Chem Biol 2000: 4; 489-494.

[67] Pradet-Balade B, Boulme F, Beug H, Mullner EW, Garcia-Sanz JA. Translation control: bridging the gap between genomics and proteomics? Trends Biochem Sci 2001: $26 ; 225-229$.

[68] Petricoin EF, Ardekani AM, Hitt BA, Levine PJ, Fusaro VA, Steinberg SM, Mills GB, Simone C, Fishman DA, Kohn EC, et al. Use of proteomic patterns in serum to identify ovarian cancer. Lancet 2002: 359; 572-577.

[69] Pompon D, Nicolas A: Protein engineering by cDNA recombination in yeasts: shuffling of mammalian cytochrome P-450 functions. Gene 1989: 83; 15-24.

[70] Heckmann-Pohl D. M., Bastian S., Altmeier S., and Antes I. Improvement of the fungal enzyme pyranose 2-oxidase using protein engineering, Journal of Biotechnology 2006: 124(1); $26-40$.

[71] Mills JC, Roth KA, Cagan RL, Gordon JI. DNA microarrays and beyond: completing the journey from tissue to cell. Nat Cell Biol 2001: 3; E175-E178.

[72] Walker J, Flower D, Rigley K. Microarrays in hematology. Curr Opin Hematol 2002:9; 23-29.
[73] Doerschuk CM. Mechanisms of leukocyte sequestration in inflamed lungs. Microcirculation 2001:8;71-88.

[74] Kurahashi K, Kajikawa O, Sawa T, Ohara M, Gropper MA, Frank DW, Martin TR, Wiener-Kronish JP. Pathogenesis of septic shock in Pseudomonas aeruginosa pneumonia. J Clin Invest 1999:104; 743-750.

[75] Korstanje R, Paigen B. From QTL to gene: the harvest begins. Nat Genet 2002: 31; 235-236.

[76] Peltonen L, McKusick VA. Genomics and medicine: dissecting human disease in the postgenomic era. Science 2001:291; 1224-1229.

[77] Spragg RG, Bernard GR, Checkley W, Curtis JR, Gajic O, Guyatt G, Hall J, Israel E, Jain M, Needham DM, Randolph AG, Rubenfeld GD, Schoenfeld D, Thompson BT, Ware LB, Young D, Harabin AL. Beyond mortality: future clinical research in acute lung injury. Am J Respir Crit Care Med 2010: 181; 1121-1127.

[78] McLachlan JB, Shelburne CP, Hart JP, Pizzo SV, Goyal R, Brooking-Dixon R, Staats HF, Abraham SN. Mast cell activators: a new class of highly effective vaccine adjuvants. Nat Med 2008: 14(5); 536-41.

[79] Alastair G Proudfoot, Matthew Hind, Mark J.D. Griffiths. Biomarkers of acute lung injury: worth their salt? BMC Medicine 2011: 9; 132

[80] Michael A. Matthay, Guy A. Zimmerman, Charles Esmon, Jahar Bhattacharya, Barry Coller, Claire M. Doerschuk, Joanna Floros, Michael A. Gimbrone Jr, Eric Hoffman, Rolf D. Hubmayr, Mark Leppert, Sadis Matalon, Robert Munford, Polly Parsons, Arthur S. Slutsky, Kevin J. Tracey, Peter Ward, Dorothy B. Gail, and Andrea L. Harabin., Future Research Directions in Acute Lung Injury; Summary of a National Heart, Lung, and Blood Institute Working Group. Am J Respir Crit Care Med 2003: 167: 1027-1035. 